\title{
APPLICATION OF BI-PRINCIPLES IN THE GATE PROJECT MANAGEMENT SYSTEM TO CREATE A DIGITAL TWIN OF THE GTE
}

\author{
O.V. Loginovskiy ${ }^{1}$, loginovskiiov@susu.ru, \\ K.A.Rizvanov², rizvanovk@bk.ru, \\ G.G. Kulikov ${ }^{3}$ \\ ${ }^{1}$ South Ural State University, Chelyabinsk, Russian Federation, \\ ${ }^{2}$ Ufa State Aviation Technical University, Ufa, Russian Federation, \\ 3 JSC "Ufa Scientific and Production Enterprise "Lightning", Ufa, Russian Federation
}

\begin{abstract}
Introduction. Currently, the Industry 4.0 concept integrates modern methodologies and practices for strategic and operational management of industrial enterprises and economies into the digital economy. It involves a wide and deep digitalization of physical and virtual objects, their connections, processes with the further possibility of their analytical analysis.

Goal of the study. Analysis of the requirements for the degree of formalization of the description of the digital twin of the production system using graphoanalytic metalanguages classified according to the Chomsky hierarchy. Materials and methods. It is proposed to use a set-theoretic and categorical approach to the classification, identification, traceability and structuring of objects of production systems and their business processes in accordance with the requirements of quality standards.

Results. The article substantiates the relevance of using intelligent business intelligence (BI) systems in the heterogeneous information space of a production system for analytical processing of semantic (content), logical and quantitative information.

Conclusion. Modern organizations are complex systems, information management of which is provided by a wide range of software, a large number of data sources makes it difficult to consolidate data and receive aggregated reports. The use of intelligent business intelligence systems will allow targeted data extraction and analytical analysis. Models of business processes are isomorphically displayed in aggregate data accumulated in information systems. That is, these models are used to structure aggregate data in the required context.

Keywords: system model, production content, formal metalanguages, subject area, analytical data processing, information retrieval system, multidimensional data classifier, business process model.
\end{abstract}

\section{Introduction}

Currently, the concept "Industry 4.0" integrates modern methodologies and practices of strategic and operational management of industrial enterprises and economies into the Digital Economy [1-4]. It assumes complete digitalization of all physical and virtual objects, their connections, processes with the further possibility of analytical analysis.

It should be noted that during their evolutionary development, information systems have accumulated and continue to accumulate significant amounts of information that can be used for planning, forecasting and decision making in various IPOs, including production systems. Further, based on the available information, a corporate knowledge base or decision support system can be built.

On the other hand, today Automated information systems of organizations use a lot of loosely coupled software packages. For example, the modern motor-building production association (UMPO) operates more than 100 different software and hardware applications supporting the corresponding activities (IPO). Most of these systems offer the possibility of local search and analysis in domain-specific languages, however, for decision-making, as a rule, simultaneous use of data from several systems is necessary, which is a difficult task, for example, because of incompatibility of systems or the use of different dictionaries data [5-8].

Fig. 1 shows the gate system of the GTE digital double, based on the CALS methodology. 


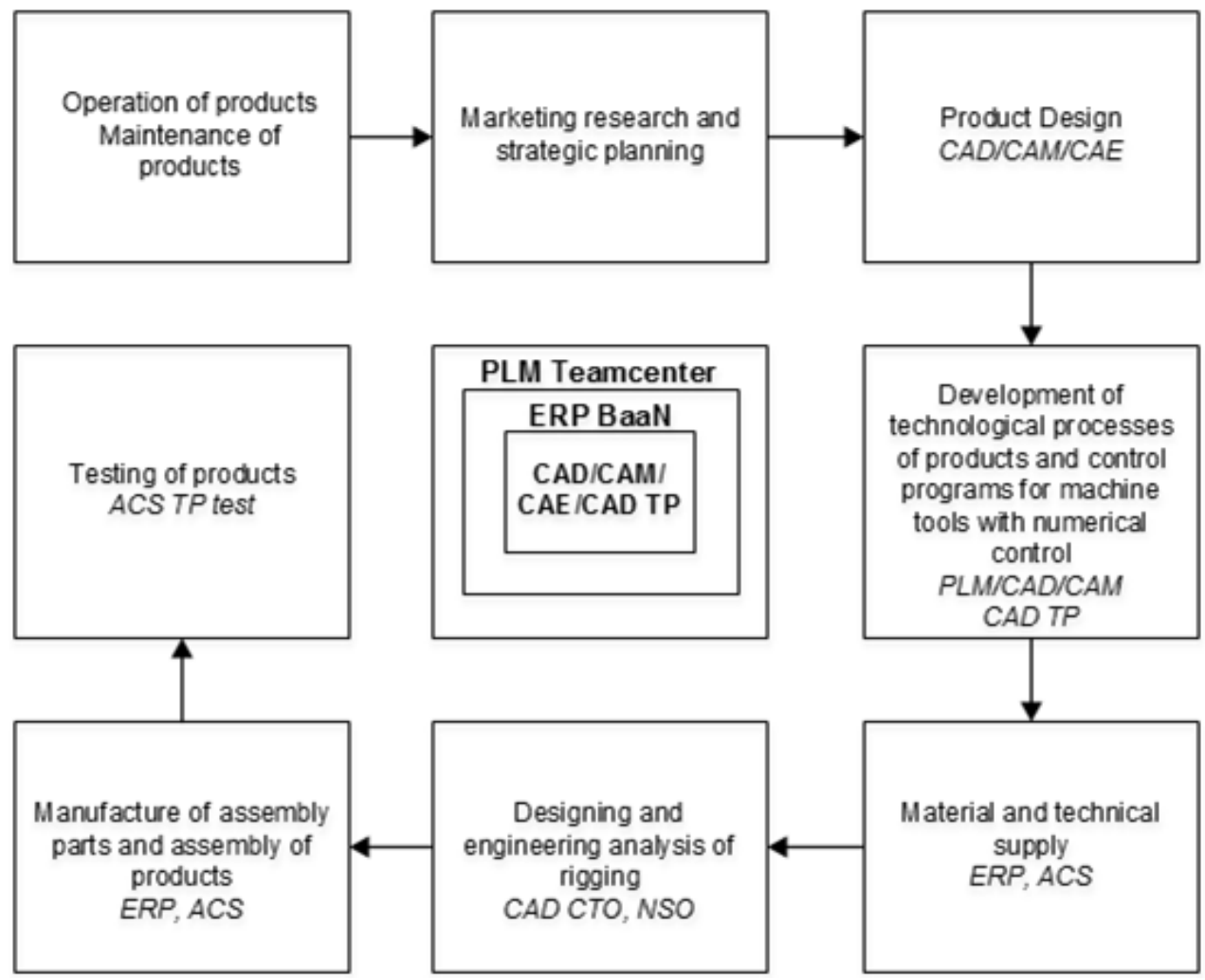

Fig. 1. Scheme of gate system of the GTE digital double

Support for the life cycle of the production of products in the machine-building enterprise is now supported by CAE-systems; CAD-systems for automation of designing and manufacturing of working design documentation; CAM-systems for automation of technological preparation of production; PDMsystems, ERP-systems for managing product data and its configurations; for the automation of production planning and management of the processes of manufacturing products, stocks, production resources, transport, etc. [5].

\section{Overview of Information Systems}

To identify and describe the goals and objectives of analytical data from multiple systems, you can use domain-specific natural language with a certain degree of formalization of syntax, for example up to a dictionary and natural rules for constructing sentences (media appropriate syllogisms) and semantics, as detailed and formalized further description of the business processes in the graph-analytical metalanguage (at a high-level programming language $[5,9,10])$. This system should be external to the objectoriented systems and subsystems consist of search and business intelligence subsystem. Today, the market presents the analytical search engines such as Google Search Appliance, Yandex.Server, IBM Content Analyst and Enterprise Search, Mondrian and others. These systems have come a long way of development from simple information retrieval systems to Business Intelligence systems with built-in mechanisms of adaptation under the IPO.

Fig. 2 shows the mimic of the system life cycle using Business Intelligence.

Consider classification, identification, traceability, structuring and analytical processing of large volumes of unstructured, structured and semi-structured distributed using the Business Intelligence methodology as an example.

Tasks solved by Business Intelligence in the enterprise [5].

- Measurement - BI creates and maintains a hierarchy of performance indicators (KPI), compares with the target value, informs stakeholders about progress in achieving business goals.

- Analytics - quantify the effectiveness of business process execution to improve efficiency and detect implicit knowledge. Often includes: data analysis, process development, statistical analysis, predictive modeling, business process modeling and other tools. 


\section{Информатика и вычислительная техника}

- Formation of corporate reporting - creates an infrastructure for the formation of reporting used in strategic management. Includes OLAP analysis, data visualization, decision support systems.

- Creation of a collaboration platform - creates a platform for collaboration both inside and outside the organization, provides storage and access to data.

- Knowledge management - the formation of a decision support system based on existing experience, support for management decisions.

\section{External environment}

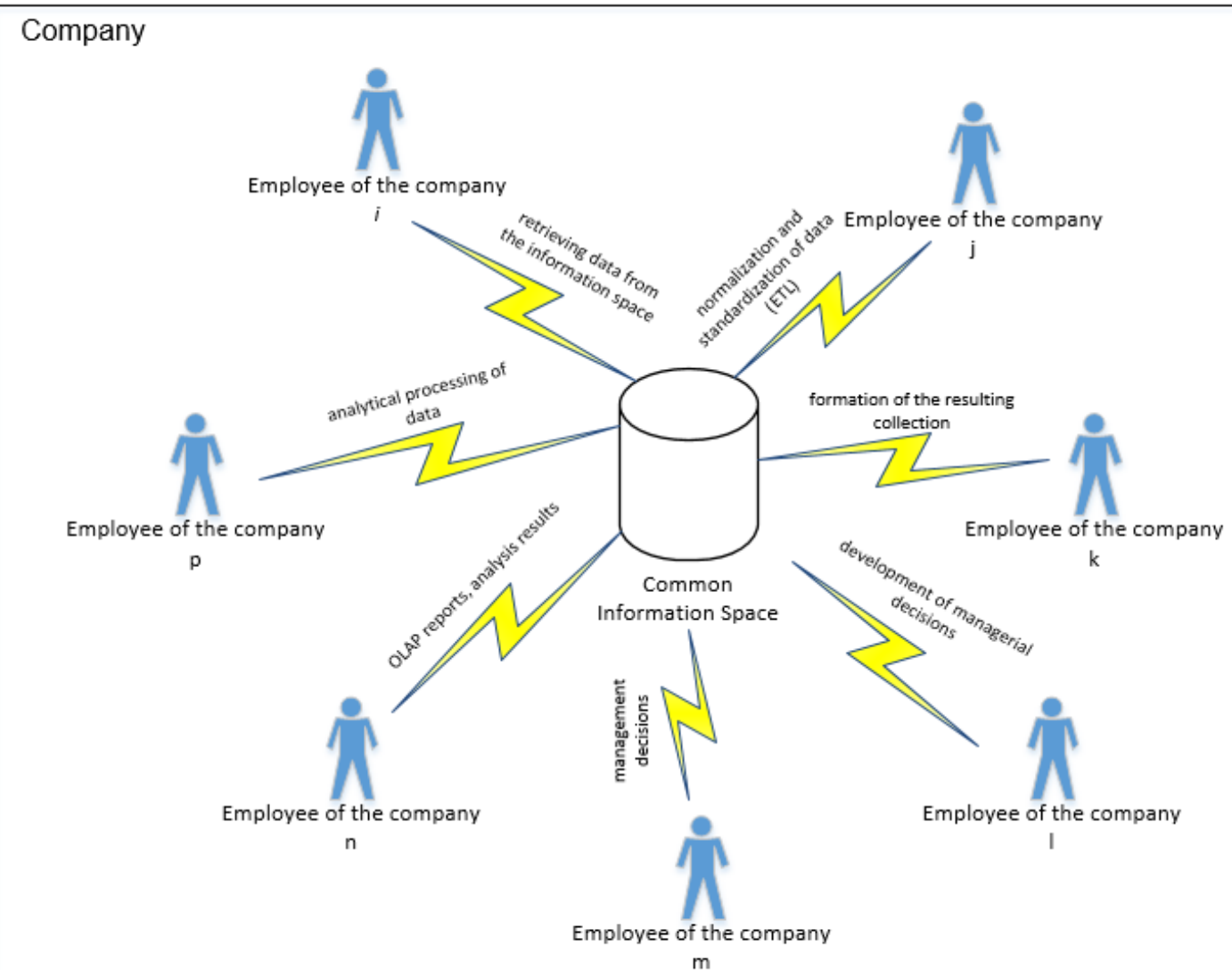

Fig. 2. Mimic of the life cycle of a system using Business Intelligence

It can be noted that the business analyst community has not yet reached a consensus on the definition of Business Intelligence. Some analysts compare it with business analysis, others with competitive intelligence systems. However, certain steps have already been taken towards standardization. So Thomas Davenport in his work "Analytics at Work" [11], defined the main stages of data preparation for analysis when using Business Intelligence systems: Data extraction; Forming reports and analytical processing in real time (OLAP); Use of tools for notification of deviations from expected values of indicators; Development of management decisions based on business analysis.

A distinctive feature of Business Intelligence systems is the ability to work with different data sources at the same time at the same time. In this regard, it is important to structure the content of sources with the potential for further processing.

The data structure of a specific information system corresponds to the model of the business process being performed. In this regard, we will use business process models to formulate criteria for structuring content and retrieving data $[9,12]$.

In order to formulate rules for structuring content, it is necessary to single out business rules from business process models, describe them in attributive form, and present them in terms of conditions. Then, based on the rules of interaction with data warehouses, you can perform data selection. 
A representation in the form of an attributive process model is necessary to enable automated processing of data based on the business process being carried out with the goal of making the model available to other systems. After the formation of the attributive model of the process, on its basis it is possible to fulfill requests to the information space in the same language in which the model is formed. If the model is built in Russian, then the requests are formed in a language similar to Russian. For example, the task is to select documents for the period from January 1 to February 10. Naturally, such a query in the DBMS can not be sent directly. Therefore, it is necessary to convert this request based on the rules of interaction with the DBMS or any data warehouses. And, in fact, after that data can already be obtained and analyzed.

In view of the distribution and heterogeneity of the organization's information space for operational access to data, it is necessary to form the classifier of information resources, believing that the task of classifying, identifying and tracing the corresponding primary resources was solved earlier. The classifier is formed on the basis of the linguistic analysis of the glossary of the system model of the business process, for example, on the formal graphical analytical metalography IDEF - using the apparatus of linguistic processing from the glossary, the terms are chosen to classify the content of a limited area of the information space.

Fig. 3 shows the scheme of the algorithm for extracting data from the information space for intellectual analysis.
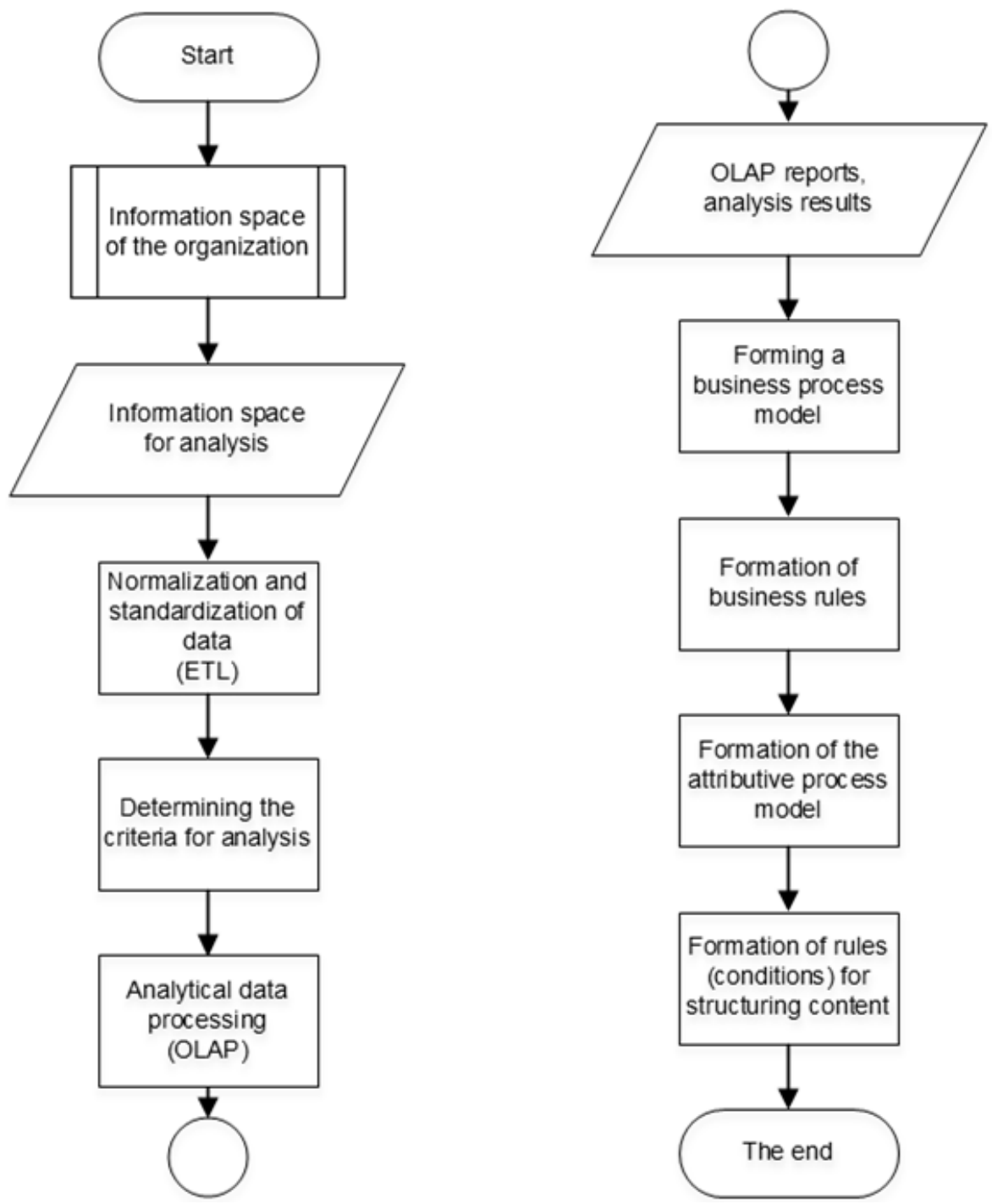

Fig. 3. Scheme of the algorithm for extracting data from the information space for intellectual analysis 


\section{Информатика и вычислительная техника}

Classification can be performed using information retrieval systems. In this case, the search index will play the role of the classifier.

When referring to the query to the classifier, it is possible to extract pointers to information resources from different systems uniformly. Representation of IPO processes and data in the language of mathematical category theory [13-16].

Fig. 4 shows the relationship between the organization's business processes and the content of the information space.

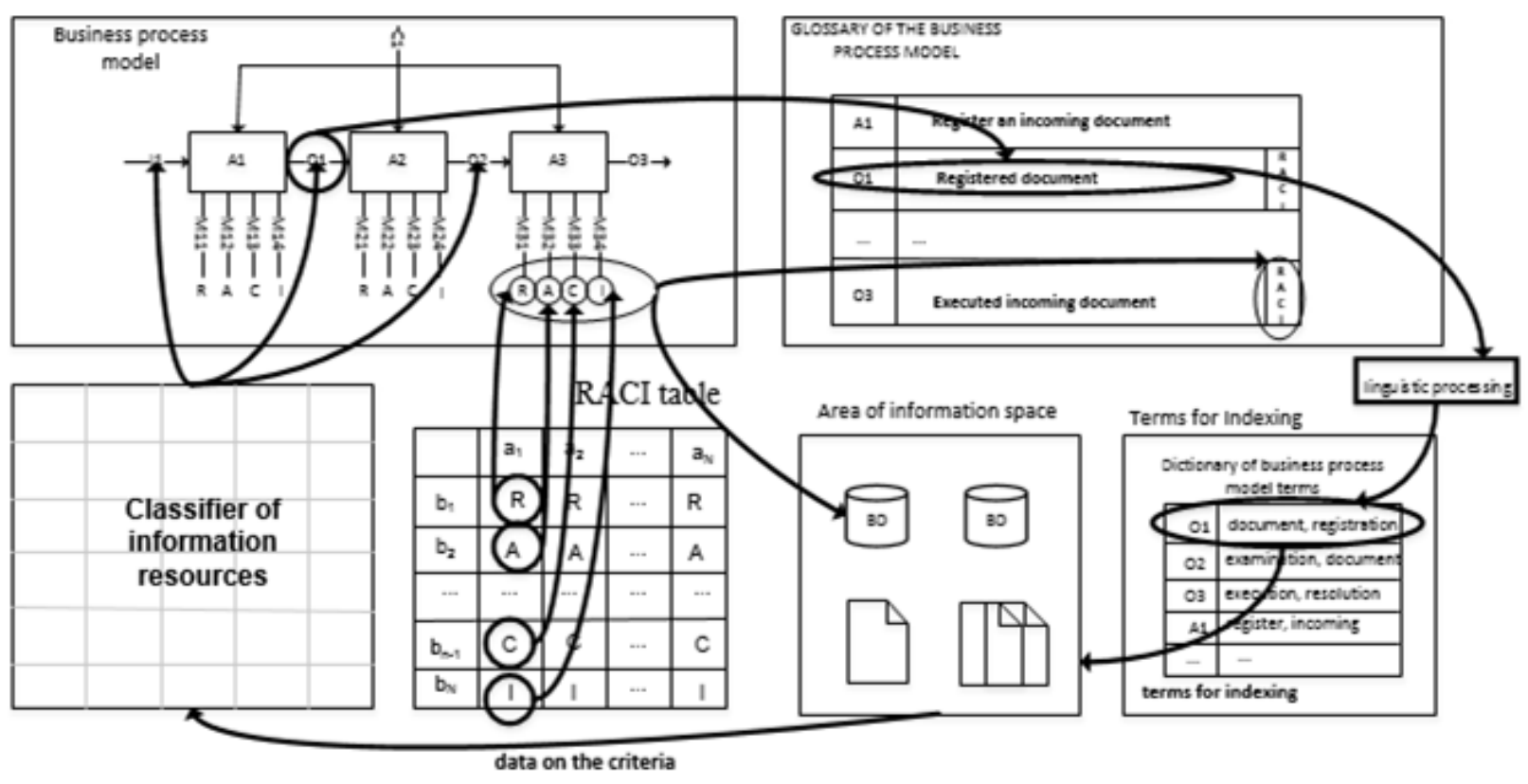

Fig. 4. The relationship between the organization's business processes and the content of the information space

Let's describe the relationship between the business process model and the content of the information space using the apparatus of the mathematical theory of categories.

The category is: a class of $\mathrm{Obj} C$ objects, for each pair of objects $A, B$ there is a set of morphisms $\operatorname{Hom}_{C}(A, B)$, and to each morphism there correspond unique $A$ and $B$, for each pair of morphisms $f \in \operatorname{Hom}_{C}(A, B)$ and $g \in \operatorname{Hom}_{C}(B, C)$ the composition $f \circ g=\operatorname{Hom}_{C}(A, C)$ is defined, for each object A the identity morphism $i d_{A} \in \operatorname{Hom}_{C}(A, A)$ is given, and two axioms are fulfilled: the composition operation is associative: $f \circ(g \circ h)=(f \circ g) \circ h$, the identity morphism acts trivially: $f \circ i d_{A}=i d_{B} \circ f=f$ for $f \in \operatorname{Hom}_{C}(A, B)$.

Establishment of relations between data is possible due to the fact that the system model satisfies the requirements of the mathematical theory of categories, i.e. there is a class of objects, a class of morphisms, the composition operation is associative, the identity morphism acts trivially. We illustrated this in system models $[17,18]$.

Let's illustrate the above provisions on the example of processing incoming and outgoing documents. We see that the categories of processing of incoming and outgoing documents can be combined into a category of a higher level - processing of correspondence.

Fig. 5 shows the processes and data in the form of a category, where on the functional model:

- class of objects - ObjC -inputs / outputs of the business process $\left(A_{1}, A_{2}, \ldots, A_{n}\right)$;

- class of morphisms - $\operatorname{Hom}_{C}\left(A_{i}, A_{j}\right)$ - functions of the business process;

- the composition operation is associative due to decomposition.

On the information model:

- class of objects $-\mathrm{Obj} C$ - the essence of the information model;

- class of morphisms - $\operatorname{Hom}_{C}\left(A_{i}, A_{j}\right)$ - relations between entities;

- the composition operation is associative due to categorization. 
On a dynamic model:

- class of objects - ObjC - tasks of the dynamic model;

- class of morphisms - $\operatorname{Hom}_{C}\left(A_{i}, A_{j}\right)$ - transitions between tasks;

- the composition operation is associative due to partitioning into subsystems.
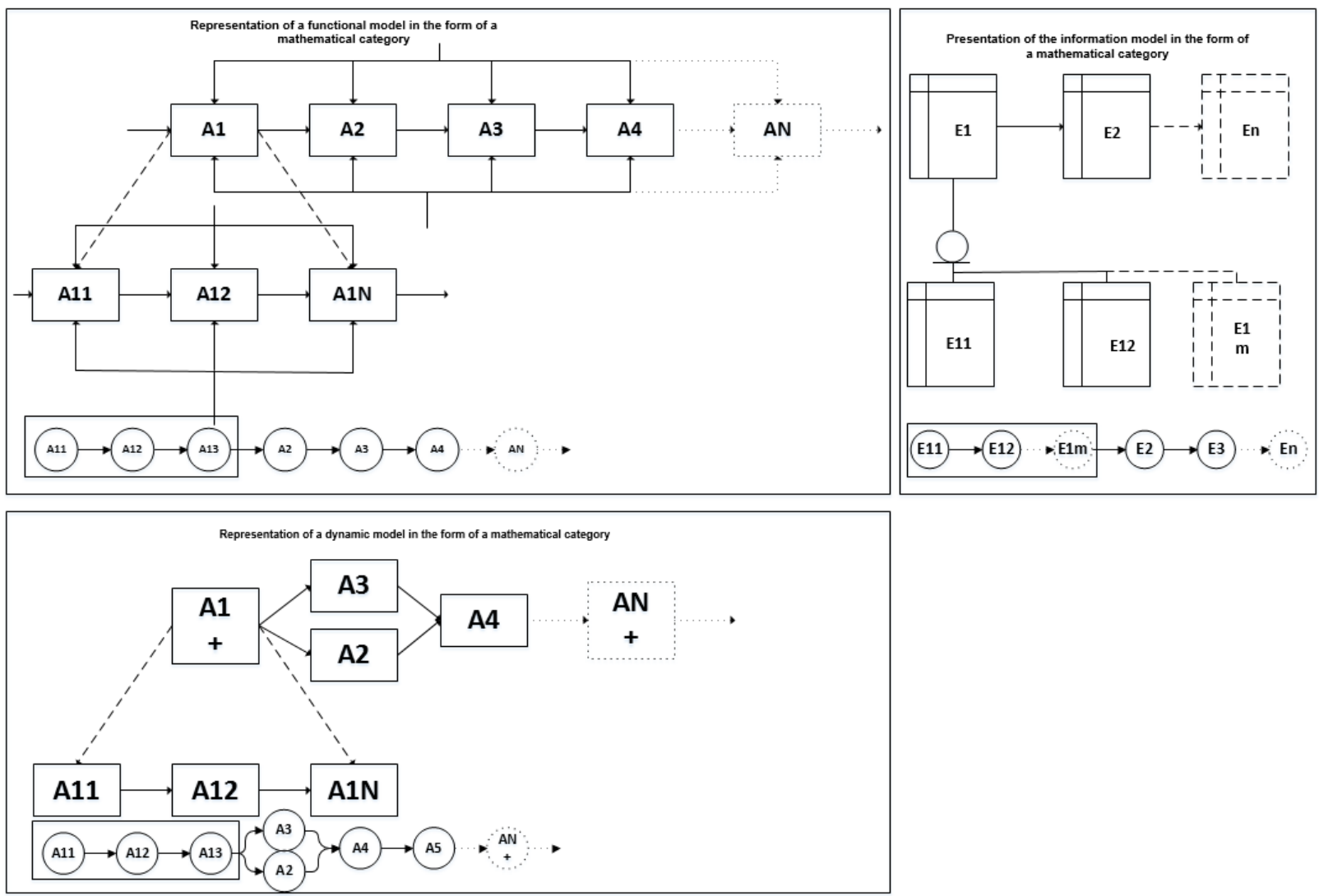

Fig. 5. Representing processes and data in the form of categories

We also illustrate the natural transformation when processing documents in the organization and transferring them to operational and archival storage.

\section{BI-system architecture}

Structuring the content of the information space and selecting the necessary data are one of the main stages of the work of the Business Intelligence system. Let's consider in addition, from what components the typical systems consist.

At the highest level is the layer of interaction with the user, i.e. it interacts with some BI application, for example, a web portal. This portal can provide the user with such opportunities as: performing business analysis, performing budgeting operations, compiling reports. This portal can receive data based on OLAP queries, corporate reporting, and any other data sources. Data can be stored in relational databases, on servers that contain integrated data for OLAP reports, in archives. Well, at the heart of this architecture is a layer that deals with administration, management, security.

Consider an example based on the IBM Cognos BI system. IBM Cognos Business Intelligence is a comprehensive solution for building an organization-wide information and analysis system.

One of the main purposes of IBM Cognos BI is data integration. The product provides the ability to continuously create reports, analyze, scoring, create dashboards and manage events, simplifying the configuration of IT and providing access to information for each employee. The result is a higher adaptation of users, better solutions and a higher dynamics of enterprise management.

IBM Cognos solutions are based on the concept of business performance management (BPM), covering the main processes of the company's management: forecasting, planning, budgeting, data consolidation, control, business analysis, financial, management and other reporting [http: // www.tadviser.ru/ index.php/Product: IBM_Cognos]. 


\section{Информатика и вычислительная техника}

The architecture of the IBM Cognos BI system is relatively simple (as for an enterprise-class system). A key element of the system is the IBM Cognos BI server, which works with data sources using a user-defined description (called metadata). Further, through Web access, the IBM Cognos BI server provides access to all the main functions of the system.

\section{Conclusions and recommendations}

Modern organizations are complex systems, information management of which is provided by a wide range of software.

A large number of data sources make it difficult to consolidate data and obtain aggregated reports.

The use of Business Intelligence systems will allow centralizing access to analytical data.

Business process models are isomorphically mapped into the data accumulated during the operation of the information system, therefore, models can also be used to structure the data in the required context.

\section{References}

1. Rasporyazhenie Pravitel'stva RF ot 28.07.2017 N 1632-r "Ob utverzhdenii programmy "Tsifrovaya ekonomika Rossiyskoy Federatsii" [The Order of the Government of the Russian Federation of 28.07.2017 N 1632-r "About the Approval of the "Digital Economy of the Russian Federation" Program].

2. Loginovskiy O.V., Maksimov A.A., Burkov V.N., Burkova I.V., Korennaya K.A., Gel'rud Ya.D., Shestekov A.L. Upravlenie promyshlennymi predpriyatiyami: strategii, mekhanizmy, sistemy. Monografiya [Management of Industrial Enterprises: Strategies, Mechanisms, Systems: Monograph]. Moscow, Infra-M Publ., 2018, 410 p.

3. Korennaya K.A., Loginovskiy O.V., Maksimov A.A. Upravlenie promyshlennymi predpriyatiyami v usloviyakh global'noy nestabil'nosti: monografiya [Management of Industrial Enterprises in Conditions of Global Instability. Monograph]. Chelyabinsk, South Ural St. Univ. Publ., 2013, $403 \mathrm{p}$.

4. Loginovskiy O.V., Lyubitsyn V.N., Nesterov M.I. Upravlenie sovremennym vuzom na baze razvitoy informatsionnoy sistemy: monografiya [Management of Modern Higher Education Institutions on the Basis of a Developed Information System. Monograph]. Chelyabinsk, South Ural St. Univ. Publ., 2013, 539 p.

5. Kulikov G.G., Barmin A.A. [Business Intelligence - Methodological and Information and Technological aspect]. Informatsionnyye tekhnologii i sistemy - 2016: trudy Pyatoy Mezhdunarodnoy nauchnoy konferentsii, Bannoye, Rossiya, 24-28 fevralya 2016 g. [Information Technologies and Systems 2016. Works of the Fifth International Scientific Conference, Bannoe, 2016]. Chelyabinsk, Chelyabinsk St. Univ. Publ., 2016, pp. 243-248. (in Russ.)

6. Rechkalov A.V., Kulikov G.G., Antonov V.V., Artyukhov A.V. [Development of a Formal Model of the Production Process Using a Corporate Information System]. Scientific Review, 2015, no. 12, pp. 187-196. (in Russ.)

7. Rechkalov A.V., Artyukhov A.V., Rizvanov K.A. [Concept of Structural and Information Organization of Situation Center for Operational Management of Machine-building Division with Territorial Production]. Bulletin of UMO. Economics, Statistics and Computer Science, 2014, no. 3, pp. 192-195. (in Russ.)

8. Rekomendatsii $R$ 50-601-36-93. Sistema kachestva. Identifikatsiya i proslezhivayemost' produktsii na predpriyatii (ISO serii 9000) [Recommendations P 50-601-36-93. Quality System. Identification and Traceability of Products in the Enterprise (ISO 9000 Series)]. Moscow, All-Russian Certification Research Institute (VNIIS) of Gosstandart of Russia, 1995.

9. Subaev M.I., Kulikov G.G., Rizvanov K.A. [Peculiarities of Development of System Model of Business Processes for Implementation in CRM System in Internet Environment]. International Journal of Applied and Fundamental Research, 2018, no. 4, pp. 29-33. (in Russ.)

10. Kulikov G.G., Shilina M.A., Shamidanov D.G. [Formalization of Causal Relations in the System Model of Knowledge on the Example of Hierarchies Chomsky]. Materialy XVII Mezhdunarodnoy 
nauchnoy konferentsii, posvyashchennoy 85-letiyu Ufimskogo gosudarstvennogo aviatsionnogo tekhnicheskogo universiteta: "Upravleniye ekonomikoy: metody, modeli, tekhnologii" [Works of XVII International Scientific Conference Dedicated to the 85th Anniversary of the UfA State Aviation Technical University "Economic Management: Methods, Models, Technologies"]. Ufa, 2017, pp. 292-294. (in Russ.)

11. Tom Davenport. Analytics at Work: Q\&A with Tom Davenport. Available at: http://www.informationweek.com/software/information-management/analytics-at-work-qanda-with-tomdavenport/d/d-id/1085869.

12. Kulikov G.G., Shilina M.A., Startsev G.V., Barmin A.A. [Structuring the Content of the Information Space of the Technical University Using the Process Approach and Semantic Identification]. Bulletin of USATU, 2014, no. 4 (65), pp. 115-124. (in Russ.)

13. Kulikov G.G., Zlobina T.P., Babak S.F., Shamidanov D.G. [System Approach to Design of Complex Intellectual Systems on the Basis of Categories of Dialectics and Formal Mathematical Settheoretic Methods]. Informatsionnyye tekhnologii i sistemy - 2017: trudy Shestoy Mezhdunarodnoy nauchnoy konferentsii, Bannoye, Rossiya, 1-5 marta $2017 \mathrm{~g}$. [Information Technologies and Systems 2017. Works of the Sixth International Scientific Conference, Bannoe, 2017]. Chelyabinsk, Chelyabinsk St. Univ. Publ., 2017, pp. 149-154. (in Russ.)

14. Rizvanov D.A., Yusupova N.I., Kuramshin D.V., Rizvanov K.A. [Algorithm and Software for Intelligent Decision Support for Resource Management of Complex Systems]. Information Technologies for Intelligent Decision Making Support (ITIDS'2016). Proceedings of the 4th International Conference. Ufa, 2016, pp. 94-99. (in Russ.)

15. Kulikov G.G., Rizvanov K.A. [Organization of the Planning System of the Machine-Building Corporation Based on the System Model of Virtual Production]. Scientific Horizons - 2015. Materials of the XI International Scientific and Practical Conference, 2015, pp. 69-74. (in Russ.)

16. Kulikov G.G., Petrov Yu.E., Rizvanov K.A. [System Model of Formation of Special Competences in a Single Information Space of Higher Educational Institution]. Sbornik statey XVII Mezhdunarodnoy nauchno-tekhnicheskoy konferentsii "Problemy informatiki v obrazovanii, upravlenii, ekonomike i tekhnike" [Proc. of the XVII International Scientific and Technical Conference "Problems of Informatics in Education, Management, Economy and Technology"]. Penza, 2017, pp. 228-233. (in Russ.)

17. Guzairov M.B., Kulikov G.G., Rizvanov K.A. The Structural Model Information System for the Production Planning. CSIT'2014, vol. 1. Sheffield, England, 2014, pp. 10-16.

18. Kulikov G.G., Petrov Yu.E., Ageev G.K., Rizvanov K.A. [Approach to Formation of Integrated Model of Special Competences (Technical Knowledge, Abilities, Skills) in Uniform Real Information Space in Real Time]. Sbornik materialov I Mezhdunarodnoy nauchno-tekhnicheskoy konferentsii "Problemy polucheniya, obrabotki i peredachi izmeritel'noy informatsii" [Collection of Materials of the I International Scientific and Technical Conference "Problems of Receiving, Processing and Transfer of Measuring Information"]. Ufa, 2017, pp. 165-167. (in Russ.)

Received 12 November 2019 


\title{
ПРИМЕНЕНИЕ ВІ-ПРИНЦИПОВ В ГЕЙТОВОЙ СИСТЕМЕ УПРАВЛЕНИЯ ПРОЕКТОМ СОЗДАНИЯ ЦИФРОВОГО ДВОЙНИКА ГТД
}

\author{
О.В. Логиновский ${ }^{1}$ К.А. Ризванов ${ }^{2}$, Г.Г. Куликов ${ }^{3}$ \\ ${ }^{1}$ Южно-Уральский государственный университет, г. Челябинск, Россия, \\ ${ }^{2}$ Уфимский государственный авиационный технический университет, г. Уфра, Россия, \\ ${ }^{3} \mathrm{AO}$ «Уфимское научно-производственное предприятие «Молния», г. Уфра, Россия
}

\begin{abstract}
Введение. В настоящее время концепция «Индустрия 4.0» интегрирует современные методологии и практики стратегического и оперативного управления промышленными предприятиями и экономиками в цифровую экономику. Она предполагает широкую и глубокую цифровизацию физических и виртуальных объектов, их связей, процессов с дальнейшей возможностью их аналитического анализа.

Цель исследования. Анализ требований к степени формализации описания цифрового двойника производственной системы при использовании графоаналитических метаязыков, классифицированных по иерархии Хомского.

Материалы и методы. Предлагается использовать теоретико-множественный и категориальный подход к классификации, идентификации, прослеживаемости и структурированию объектов производственных систем и их бизнес-процессов в соответствии с требованиями стандартов качества.

Результаты. В статье обоснована актуальность использования интеллектуальных систем бизнес-аналитики (BI) в неоднородном информационном пространстве производственной системы для аналитической обработки семантической (контента), логической и количественной информации.

Заключение. Современные организации представляют собой сложные системы, информационное управление которыми обеспечивается широким спектром программного обеспечения, большое число источников данных затрудняет консолидацию данных и получение агрегированных отчетов. Использование интеллектуальных систем бизнес-аналитики позволит целенаправленно извлекать данные и проводить их аналитический анализ. Модели бизнеспроцессов изоморфно отображаются в агрегатные данные, накапливаемые в информационные системы. То есть эти модели используются для структурирования агрегатных данных в требуемом контексте.

Ключевые слова: системная модель, иифровой двойник, производственный контент, формальные метаязыки, предметная область, интеллектуальная аналитическая обработка данных, информационно-поисковая система, многомерный классификатор данных, модель бизнес-проиессов.
\end{abstract}

\section{Лumepamypa}

1. Распоряжение Правительства РФ от 28.07.2017 N 1632-р «Об утверждении программы «Цифровая экономика Российской Федерачии».

2. Управление промышленными предприятиями: стратегии, механизмы, системы: моногр. / О.В. Логиновский, А.А. Максимов, В.Н. Бурков и др.; под ред. заслуж. деятеля науки РФ О.В. Логиновского, д-ра техн. наук А.А. Максимова. - М.: Инфра-М, 2018. - 410 c.

3. Коренная, К.А. Управление промышленными предприятиями в условиях глобальной нестабильности: моногр. / К.А. Коренная, О.В. Логиновский, А.А. Максимов; под ред. д-ра техн. наук, проф. А.Л. Шестакова - Челябинск: Издат. иентр ЮУрГУ, 2013. - 403 с.

4. Логиновский, О.В. Управление современным вузом на базе развитой информачионной системы: моногр. / О.В. Логиновский, В.Н. Любииын, М.И. Нестеров; под ред. д-ра техн. наук, проф. А.Л. Шестакова - Челябинск: Издат. центр ЮУрГУ, 2013. - 539 с.

5. Куликов, Г.Г. Виsiness intelligence - методологический и информачионно-технологический аспект / Г.Г. Куликов, А.А. Бармин // Информационные технологии и системы - 2016: тр. Пятой 
Междунар. науч. конф., Банное, Россия, 24-28 февраля 2016 г. - Челябинск: Изд-во Челяб. гос. ун-та, 2016. - C. 243-248.

6. Разработка формальной модели производственного прочесса с применением корпоративной информачионной системы. / А.В. Речкалов, Г.Г. Куликов, В.В. Антонов, А.В. Артюхов // Научное обозрение. - 2015. - № 12. - С. 187-196.

7. Речкалов, А.В. Концепиия структурно-информаџионной организачии ситуационного иентра для оперативного управления машиностроительным дивизионом с территориальнораспределенным производством / А.В. Речкалов, А.В. Артюхов, К.А. Ризванов // Вестник УМО. Экономика, статистика и информатика. - 2014. - № 3. - С. 192-195.

8. Рекомендации Р 50-601-36-93. Система качества. Идентификация и прослеживаемость продукции на предприятии (ИСО серии 9000). - М.: Всероссийский научно-исследовательский институт сертификаџии (ВНИИС) Госстандарта России, 1995.

9. Субаев, М.И. Особенности разработки системной модели бизнес-проиессов для реализаичи в СRМ системе в Internet среде / М.И. Субаев, Г.Г.Куликов, К.А. Ризванов // Международный журнал прикладных и фундаментальных исследований. - 2018. - № 4. - С. 29-33.

10. Куликов, Г.Г. Формализачия причинно-следственных связей в системной модели знаний на примере иерархий Хомского / Г.Г. Куликов, М.А. Шилина, Д.Г. Шамиданов // Сборник материалов XVII Международной научной конференции, посвященной 85-летию Уфимского государственного авиационного технического университета «Управление экономикой: методы, модели, технологии». - Уфа: Изд-во УГАТУ, 2017. - С. 292-294.

11. Tom Davenport. Analytics at Work: Q\&A with Tom Davenport. - peжuм достуna: http://www.informationweek.com/software/information-management/analytics-at-work-qanda-with-tomdavenport/d/d-id/1085869.

12. Структурирование контента информачионного пространства технического университета с использованием процессного подхода и семантической идентификации / Г.Г. Куликов, М.А. Шилина, Г.В. Стариев, А.А. Бармин // Вестник УГАТУ. - 2014. - № 4 (65). - С. 115-124.

13. Системный подход к проектированию сложных интеллектуальных систем на основе категорий диалектики и формальных математических теоретико-множественных методов / Г.Г. Куликов, Т.П. Злобина, С.Ф. Бабак, Д.Г. Шамиданов // Информащионные технологии и системы - 2017: тр. Шестой Междунар. науч. конф., Банное, Россия, 1-5 марта 2017 г. - Челябинск: Изд-во Челяб. гос. ун-та, 2017. - С. 149-154.

14. Алгоритмическое и программное обеспечение интеллектуальной поддержки принятия решений при управлении ресурсами сложных систем / Д.А. Ризванов, Н.И. Юсупова, Д.В. Курамшин, К.А. Ризванов // Information Technologies for Intelligent Decision Making Support (ITIDS'2016). Proceedings of the 4th International Conference. - 2016. - C. 94-99.

15. Куликов, Г.Г. Организация системы планирования машиностроительной корпорации на основе системной модели виртуального производства / Г.Г. Куликов, К.А. Ризванов // Scientific horizons - 2015. Materials of the XI International scientific and practical conference. - 2015. C. 69-74.

16. Куликов, Г.Г. Системная модель формирования специальных компетенций в едином информационном пространстве высшего учебного заведения / Г.Г. Куликов, Ю.Е. Петров, К.А. Ризванов // Сборник статей XVII Международной научно-технической конференции «Проблемы информатики в образовании, управлении, экономике и технике»; под ред. В.И. Горбаченко, В.В. Дрождина. - Пенза: Приволжский дом знаний, 2017. - C. 228-233.

17. Guzairov, M.B., Kulikov G.G., Rizvanov K.A. The structural model information system for the production planning // CSIT 2014. - Sheffield, England, 2014. - Vol. 1. - P. 10-16.

18. Подход к формированию интегральной модели специиальных компетенций (технических знаний, умений, навыков) в едином реально-информачионном пространстве в реальном времени / Г.Г. Куликов, Ю.Е Петров, Г.К. Агеев, К.А. Ризванов // Сборник материалов I Международной научно-технической конференции «Проблемы получения, обработки и передачи измерительной информации». - Уфа: РИК УГАТУ, 2017. - С. 165-167. 


\section{Информатика и вычислительная техника}

Логиновский Олег Витальевич, д-р техн. наук, профессор, заведующий кафедрой информационно-аналитического обеспечения управления в социальных и экономических системах, Южно-Уральский государственный университет, г. Челябинск; loginovskiyo @ mail.ru.

Ризванов Константин Анварович, канд. техн. наук, доцент кафедры автоматизированных систем управления, Уфимский государственный авиационный технический университет, г. Уфа; rizvanovk@bk.ru.

Куликов Григорий Геннадьевич, технический директор, АО «Уфимское научно-производственное предприятие «Молния», г. Уфа.

Поступила в редакцию 12 ноября 2019 2.

\section{ОБРАЗЕЦ ЦИТИРОВАНИЯ}

Loginovskiy, O.V. Application of BI-Principles in the Gate Project Management System to Create a Digital Twin of the GTE / O.V. Loginovskiy, K.A. Rizvanov, G.G. Kulikov // Вестник ЮУрГУ. Серия «Компьютерные технологии, управление, радиоэлектроника». 2020. - T. 20, № 1. - C. 16-26. DOI: 10.14529/ctcr200102

\section{FOR CITATION}

Loginovskiy O.V., Rizvanov K.A., Kulikov G.G. Application of BI-Principles in the Gate Project Management System to Create a Digital Twin of the GTE. Bulletin of the South Ural State University. Ser. Computer Technologies, Automatic Control, Radio Electronics, 2020, vol. 20, no. 1, pp. 16-26. DOI: 10.14529/ctcr200102 